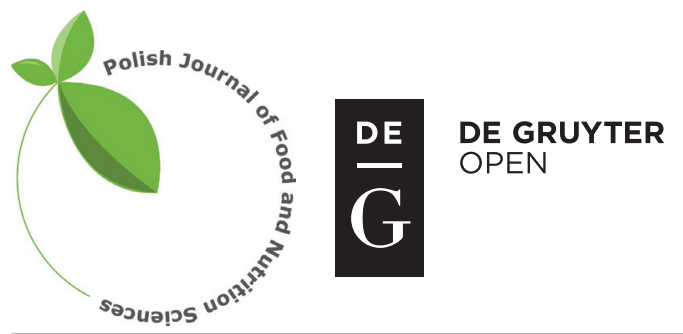

Pol. J. Food Nutr. Sci., 2018, Vol. 68, No. 4, pp. 359-365

DOI: $10.2478 /$ pjfns-2018-0003 http://journal.pan.olsztyn.pl

Original research article

Section: Food Quality and Functionality

\title{
Effect of Elicitors as Stimulating Substances on Sensory Quality Traits in Color Sweet Bell Pepper (Capsicum annuum L. cv. Fascinato and Orangela) Grown under Greenhouse Conditions
}

\author{
Sandra N. Jimenez-Garcia ${ }^{1}$, Moisés A. Vázquez-Cruz ${ }^{4}$,Rita Miranda-Lopez ${ }^{3}$,Lina Garcia-Mier, \\ Ramon G. Guevara-González², Ana A. Feregrino-Perez ${ }^{2 *}$
}

\author{
'Departamento de Enfermería y Obstetricia, División de Ciencias de la Salud e Ingeniería, Campus Celava-Salvatierra, \\ Universidad de Guanajuato, Av. Mutualismo Esq. Prolongación Río Lerma S/N, Celaya, Guanajuato, C.P. 38060, México \\ ${ }_{2}^{2}$ División de Estudios de Posgrado, C.A. Ingeniería de Biosistemas, Facultad de Ingeniería, Universidad Autónoma de Querétaro, \\ C.U. Cerro de las Campanas S/N, Colonia Las Campanas, C.P. 76010, Santiago de Querétaro, Querétaro, México \\ ${ }^{3}$ Departamento de Ingeniería Bioquímica, Instituto Tecnológico de Celaya, Av. Tecnológico esq. García Cubas s/n, \\ Celaya, Guanajuato, C.P. 38000, México \\ ${ }^{4}$ Universidad del Valle de México. Campus Querétaro. Departamento de Ciencias de la Salud. Blvd. Juriquilla No. 1000 A, \\ Delegación Santa Rosa Jáuregui, Santiago de Querétaro, Qro., CP 76230, Mexico
}

Key words: Capsicum annuum, elicitors, sensory evaluation, flavor, principal component analysis (PCA), multiple linear regressions (MLR)

The effect of the application of salicylic acid (SA) and hydrogen peroxide $\left(\mathrm{H}_{2} \mathrm{O}_{2}\right)$ was evaluated on sensory quality traits of two commercial sweet bell pepper varieties, Fascinato and Orangela, by descriptive sensory evaluation, principal component analysis (PCA), and Multivariate Analysis of Variance (MANOVA). A sensory descriptive lexicon was established for the sweet pepper and an intensity score was assigned for 25 sensory attributes in all the samples. Such intensity score was performed by twelve trained panelists. Among the results it was shown that foliar application of elicitors to pepper crop produced significant differences in sensory traits of the harvested fruits. MANOVA allowed detecting differences in aroma profile among treatments and varieties, showing important changes depending on the combination of elicitors applied on each variety. The principal component analysis (PCA), showed that the PC1 explained $81.02 \%$, while PC2 explained $9.24 \%$ of the variance in the results. A strong correlation between varieties and treatments $2\left(36 \mathrm{mM} \mathrm{H}_{2} \mathrm{O}_{2}\right)$ and $4\left(0.1 \mathrm{mM} \mathrm{SA}\right.$ and $\left.36 \mathrm{mM} \mathrm{H}_{2} \mathrm{O}_{2}\right)$ with $\mathrm{PC} 1$ was observed. Treatments 2 and 4 were related to changes in aroma and flavor traits. Fascinato was more susceptible to the effect of elicitor than Orangela. Therefore, elicitor combinations used in this experiment were capable to improve sensory quality of peppers, and not only promote an increase in shelf life as previous studies have shown.

\section{INTRODUCTION}

Sweet pepper (Capsicum annuum, L.) is one of the most important commercial vegetable crops worldwide and a component of the traditional human diet, it is a good source of antioxidants, flavonoids, phenolic acids and carotenoids [Castro et al., 2008; Ilić et al., 2017; Raybaudi-Massilia et al., 2017]. Consumers purchasing decisions are commonly focused on the color, size, firmness and other quality features [Maalekuu et al., 2004]. Nowadays, scientities have studied not only the physical characteristics of sweet peppers, but also, their nutritional and nutraceutical characteristics [Simonne et al., 1997]. The loss of water in the sweet peppers is one of the problems that are generated during storage, causing a change of their texture [Jacxsens et al., 2002]. Consumers have become more critical in the last decade, taking into account flavor and texture as quality parameters

\footnotetext{
* Corresponding Author: Tel: +52 014421921200 ext. 6016

E-mail: feregrino.angge@hotmail.com (Ana A. Feregrino-Perez)
}

[Rodríguez-Burruezo et al., 2010]. In fact, Asian culture has considered the heat sensation produced by peppers as one of the six main taste sensations, along with bitter, sweet, sour, salty, and umami. No descriptive vocabulary or lexicon exists to describe the complex nature of this sensory experience. A standardized vocabulary that objectively describes the sensory properties of this food product and facilitates communication across diverse audiences is, therefore, needed [Guzmán \& Bosland, 2017].

Among the promising approaches for inducing plant disease resistance and reducing stress damage, and stimulating plant growth is the application of different elicitors, like hydrogen peroxide $\left(\mathrm{H}_{2} \mathrm{O}_{2}\right)$ and salicylic acid (SA). The immune defense responses in plants are induced by stable molecules caused by the elicitor's compound [Zimmermann \& Schieberle, 2000; Holopainen et al., 2009]. Very few efforts have been done to study the effects of elicitors on plant growth, productivity, and changes in fruit quality traits of commercial interest, since they are only applied mainly as antimicrobials to protect plants from soil pathogens or to increase storability of fruits such as strawberry [Vargas et al., 2006; Simões et al., 2009]. 
The experimental analyses are mainly applied for the combination of sensory attributes, assessed by a trained panel of judges on different products. Regarding sweet bell pepper, few sensory studies have been performed so far and included only the evaluation of its aroma properties but not the the identification of its sensory properties as appearance, taste, flavor, and mouthfeel important to consumer acceptance [Berrueta et al., 2007; Westad et al., 2003]. Analysis of multivariate data, such as analysis of variance (MANOVA), helps us to interrelate between varieties of cultivars and variables, it is important to extract the interpretable and statistically reliable information [Guillén-Casla et al., 2010]. Thus, the principal component analysis (PCA) was used as a feature selection method for clustering the descriptors and choosing the best ones [Rajalahti \& Kvalheim, 2011]. The aim of this work was to evaluate the effect of foliar application of $\mathrm{SA}$ and $\mathrm{H}_{2} \mathrm{O}_{2}$ on sensory quality attributes related mainly to the aroma, flavor, and texture of sweet bell peppers (Capsicum annuum L.) of two varieties: Fascinato and Orangela, by means of MANOVA and PCA.

\section{MATERIALS AND METHODS}

\section{Plant material}

Two sweet pepper varieties (Capsicum annuum L. cv. Fascinato and Orangela), used in this study were grown under greenhouse conditions, using coir as substrate and drip irrigated nutrient solution. Regular cultural practices were applied to the plants during their development. Plants were scattered in 20 rows, with separation of $1.5 \mathrm{~m}$ between rows and $0.30 \mathrm{~m}$ within each row, resulting in a plant density of 3.2 plants $/ \mathrm{m}^{2}$ and a total of 1530 plants. Each treatment had 60 plants for three repetitions randomly distributed. The experiment was performed for 180 days in CEICKOR facilities (Koppert Rapel Research and Training Center) located at Ezequiel Montes, Colon, Querétaro, México.

\section{Experimental design}

We evaluated the effect of foliar application of two elicitors, salicylic acid (SA) and hydrogen peroxide $\left(\mathrm{H}_{2} \mathrm{O}_{2}\right)$, at three different concentrations as experimental treatments, and one control treatment (Table 1). Treatments were applied in a complete randomized block design. Each experimental unit had 60 plants. Each treatment was replicated three times.

\section{Sweet pepper sampling}

Peppers were harvested when $90-100 \%$ of their surface was colored. All samples were kept at $18^{\circ} \mathrm{C}$ and $80 \% \mathrm{RH}$ prior their transportation for sensory analysis at the Technological Institute of Celaya (Celaya, Guanajuato, México). Pepper samples were taken out before the evaluations in order to reach room temperature $\left(23^{\circ} \mathrm{C}\right)$. For each sensory assay, batches of 5 sweet peppers were randomly selected to make a demonstrative sample. Peppers were cut into $1 \mathrm{~cm}$ pieces.

\section{Sensory lexicon development and orientation}

The two sweet pepper varieties were subjected to sensory evaluation by a knowledgeable descriptive expert panel of twelve panelists, 8 women and 4 men. All panelists completed $150 \mathrm{~h}$
TABLE 1. Summary of treatments applied to sweet pepper.

\begin{tabular}{l|c|c}
\hline Treatment & $\begin{array}{c}\text { Salicylic acid }(\mathrm{SA}) \\
(\mathrm{mM})\end{array}$ & $\begin{array}{c}\text { Hydrogen peroxide }\left(\mathrm{H}_{2} \mathrm{O}_{2}\right) \\
(\mathrm{mM})\end{array}$ \\
\hline Control (T1) & 0 & 0 \\
T2 & 0 & 36 \\
T3 & 0.1 & 0 \\
T4 & 0.1 & 36 \\
T5 & 0.01 & 18 \\
\hline
\end{tabular}

of general training in descriptive analysis following the Spectrum ${ }^{\circledR}$ methodology by Meilgaard et al. [2006] covering several sensory attributes related to appearance, aroma, flavor, texture, and aftertaste, the score of intensity for such attributes ranged from 0 (low intensity) to 15 (extreme intensity). During training, the panelists were conducted through orientation sessions in order to know and develop the particular set of descriptors for the assessment. In previous studies, a set of descriptors was developed based on Wine Aroma Wheel ${ }^{\circledR}$ (ann@winearomawheel.com), which was adapted to sweet bell pepper so the panelists could use it in this descriptive assessment; the panelists were given indications to carry out the sensory analysis. Later, they made discussions to compare terminologies and thus to be able to select the most representative descriptors of lexicon. The sensory characteristics of each sweet pepper were grouped by affinity. Panelists were trained with these descriptors over a period of approximately three months to ensure a consistent assessment. Samples were evaluated at an average temperature of $23 \pm 1^{\circ} \mathrm{C}$. The references listed in the lexicon were provided to the panelists so that they would relate to the terminology used in this evaluation and thus can clarify definitions or references of the attributes to be analyzed in the sweet pepper. There were 25 attributes included in the lexicon as aroma, flavor and texture. Table 2 lists the attributes, acronyms, and definitions used for testing.

\section{Test design and sample evaluation}

The complete random block design was used to run the tests of this study. Sweet peppers were removed from the freezer one hour before each test and allowed to reach room temperature $\left(23 \pm 1^{\circ} \mathrm{C}\right)$. In the morning of evaluation day, the peppers were cut into $1 \mathrm{~cm}$ cubic pieces, three pieces per variety were served in a plastic dish and offered to each panelist. Samplea on each of the dishes were labeled with a 3-digit code. They were provided with references for attributes with definition/reference sheets. The samples to be analyzed were provided to each panelist in pieces of a cubic centimeter to evaluate texture and to be able to put in the mouth and to chew. The panelists were given unsalted and tasteless biscuits and water to wash their mouths between each sample to have no errors in the evaluation. Panelists evaluated pepper samples in triplicate for each of the two cultivars and treatments. A replicate was completed in 1 day during a 60 minute evaluation session, for a total of four days a week, for three weeks. Panelist performance was checked prior to the test and reviewed again after the test. In both cas- 
TABLE 2. Pepper fruits sensory descriptors and definitions.

\begin{tabular}{|c|c|c|}
\hline Descriptor & Acronyms & Definition \\
\hline \multicolumn{3}{|c|}{ Aroma } \\
\hline Global & ArGlob & $\begin{array}{l}\text { Strength of the overall } \\
\text { perception. }\end{array}$ \\
\hline Fruity & $\mathrm{ArFr}$ & $\begin{array}{l}\text { Related to lemon, orange } \\
\text { and grapefruit notes. }\end{array}$ \\
\hline Floral & ArFlo & $\begin{array}{l}\text { Related to geranium, } \\
\text { violet and rose notes. }\end{array}$ \\
\hline Vegetative-cooked & ArVCoc & $\begin{array}{l}\text { Related to cooked } \\
\text { vegetables notes. }\end{array}$ \\
\hline Vegetative-Fresh & ArVTalPP & Related to green leaves notes. \\
\hline Vegetative-herbal & ArVHeRa & $\begin{array}{l}\text { Related to hay } \\
\text { and branch notes. }\end{array}$ \\
\hline Spicy & ArEPim & Related to spices notes. \\
\hline $\begin{array}{l}\text { Chemical-spicy- } \\
\text { pungent }\end{array}$ & ArQAcAE & $\begin{array}{l}\text { Related to acetic acid } \\
\text { and ethanol notes. }\end{array}$ \\
\hline Chemical-cardboard & ARQCartH & $\begin{array}{l}\text { Related to paper and wet } \\
\text { cardboard notes. }\end{array}$ \\
\hline Chemical-plastic & ARQPlast & $\begin{array}{l}\text { Related to oil, plastic } \\
\text { and petroleum notes. }\end{array}$ \\
\hline Chemical-sulphur & ArQColc & $\begin{array}{l}\text { Related to cooked } \\
\text { cabbage notes. }\end{array}$ \\
\hline Caramelized-honey & ArCCarM & $\begin{array}{l}\text { Related to caramel, maple } \\
\text { syrup and honey notes. }\end{array}$ \\
\hline Pungen-hot & ArPalch & Related to ethanol notes. \\
\hline Pungent-fresh & ArPMent & $\begin{array}{l}\text { Related to grass, eucalyptus } \\
\text { and mint notes }\end{array}$ \\
\hline Pungent & ArPun & Related to spicy notes. \\
\hline \multicolumn{3}{|c|}{ Flavor } \\
\hline Sweet & SDul & $\begin{array}{l}\text { Sensation related to } \\
\text { different sugar solutions }\end{array}$ \\
\hline Salty & SSal & $\begin{array}{l}\text { Sensation related to } \\
\text { different salt solutions }\end{array}$ \\
\hline Acid & SAc & $\begin{array}{l}\text { Sensation related to different } \\
\text { citric acid solutions }\end{array}$ \\
\hline Bitter & SAm & $\begin{array}{l}\text { Sensation related to different } \\
\text { caffeine solutions }\end{array}$ \\
\hline Umami & SUm & $\begin{array}{l}\text { Sensation related to different } \\
\text { glutamic acid solutions. }\end{array}$ \\
\hline Spicy-pungent & SPic & $\begin{array}{l}\text { Sensation related to different } \\
\text { capsaicin solutions }\end{array}$ \\
\hline Vegetative-fresh & SVegFres & $\begin{array}{l}\text { Sensation related to } \\
\text { lettuce, stem, and lawn. }\end{array}$ \\
\hline \multicolumn{3}{|c|}{ Texture } \\
\hline External hardness & TBPCFirm & $\begin{array}{l}\text { Force required compressing } \\
\text { the sample against the palate. }\end{array}$ \\
\hline Cohesiveness & TBPCCoh & $\begin{array}{l}\text { Amount of sample that } \\
\text { deforms rather than cut. }\end{array}$ \\
\hline First bite hardness & TBPCDur & $\begin{array}{l}\text { Toughness of a product } \\
\text { when biting with incisors }\end{array}$ \\
\hline
\end{tabular}

es, the panelists showed consistency in the results and minimum standard deviations, so panelists were not considered as a variation source in the statistical analysis.

\section{Statistical analysis}

A total of 216 measurements per attribute were analyzed for the two pepper varieties. These data were analyzed
TABLE 3. MANOVA results obtained for the sensory analysis applied to the sweet pepper samples.

\begin{tabular}{|c|c|c|c|c|}
\hline $\begin{array}{l}\text { Sensory } \\
\text { characteristic }\end{array}$ & Attribute $^{\mathrm{a}}$ & A:Variety & B:Treatment & $\mathrm{AB}$ \\
\hline \multirow{10}{*}{ Aroma } & ArGlob & **** & $* * *$ & $* * *$ \\
\hline & ArFru & $* * * *$ & & \\
\hline & ArVCoc & $* *$ & & \\
\hline & ArVTalPP & $* * * *$ & $*$ & \\
\hline & $\mathrm{ArVHeRa}$ & $* * * *$ & & \\
\hline & ArEPim & * & & \\
\hline & ArQPlast & $* * * *$ & & \\
\hline & ArQColC & $* * *$ & $*$ & $*$ \\
\hline & ArPMent & $* * *$ & $* *$ & $* *$ \\
\hline & ArPun & $* * *$ & $*$ & $* * * *$ \\
\hline \multirow{5}{*}{ Flavor } & SDul & $* * *$ & $* * *$ & $* * *$ \\
\hline & SSal & $* * *$ & & \\
\hline & SAc & $* * *$ & $*$ & * \\
\hline & SPic & $* *$ & & \\
\hline & SVegFres & $* * * *$ & $* *$ & $* * *$ \\
\hline \multirow{3}{*}{ Texture } & TBPCFirm & $* *$ & $*$ & * \\
\hline & TBPCCoh & $* * *$ & $*$ & $*$ \\
\hline & TBPMDur & $* * *$ & & \\
\hline
\end{tabular}

${ }^{\mathrm{a}}$ Acronyms of attributes as provided in Table $2 .{ }^{*} \mathrm{p}=0.05,{ }^{* *} \mathrm{p}=0.005$, $* * * \mathrm{p}=0.001$.

by means of MANOVA and PCA. The software package STATGRAPHICS Centurion XVI version 16.1.11 (StatPoint Technologies, Inc., 2010) was employed.

\section{RESULTS}

The data collected for aroma, flavor, and texture sensory descriptors in the different treatments and among the two pepper varieties were analyzed. Sensory analysis is a well-organized technique to describe these properties in foods. It needs to be mentioned that the relationship between sweet pepper and sensory characteristics is, mostly, that flavor derives from the relation of reducing sugars to organic acids and volatile aromas. In this regard, volatiles contribute to the specific aroma of sweet pepper. Sweetness and acidity are also related to sugar and acid content. Texture features are more complex to relate to physical measures, although firmness of a sweet pepper measured by mouth is partly related to instrumental determination by means of texture analyzers [vanRuth \& Roozen, 1994; Guzmán \& Bosland, 2017].

\section{Quantitative descriptive analysis}

The factors: variety and treatment, and the interaction of both, affected the intensity of the sensory attributes of samples. Table 3 summarizes significant changes in 18 attributes belonging to aroma, flavor and texture for sweet pepper variet- 


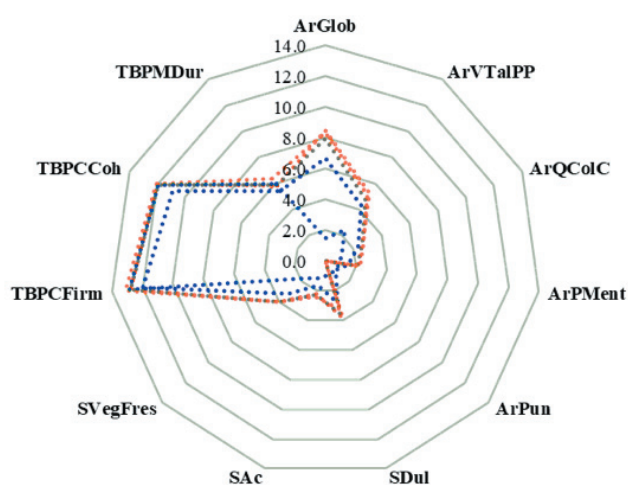

a)

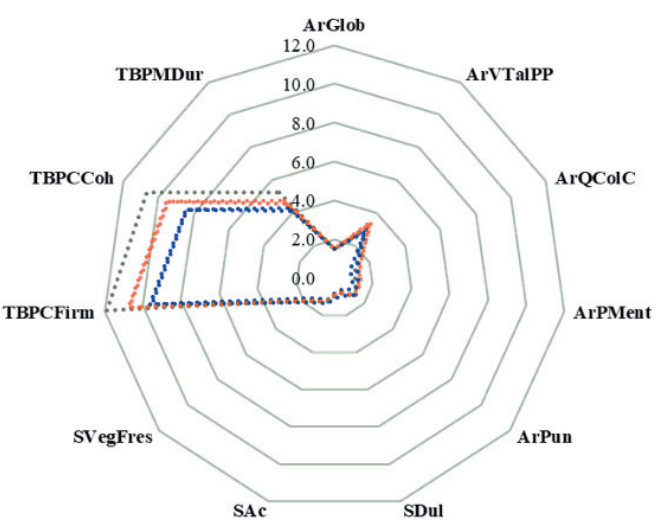

b)

FIGURE 1. Results of the descriptive analysis of sensory attributes in a) Fascinato and b) Orangela sweet peppers.

Treatments (T1-T5) as provided in Table 1. Acronyms as provided in Table 2.

ies under the evaluated treatments. Sensory attributes showed highly significant differences between varieties. The less affected attributes by the treatments in this experiment were all related to texture. In order to appreciate the changes in attributes caused by variety and treatments, the results achieved for all sensory characteristics are shown as radial graphics in Figures 1a and 1b.

For Fascinato sweet pepper, global aroma showed the highest intensity for treatments 2,3 and 4 . It seems that global aroma intensity increased as $\mathrm{H}_{2} \mathrm{O}_{2}$ concentration in- creased (Figure 1a). Other attributes with a similar tendency were sweet flavor and external hardness. The strongest intensity was noted for the samples obtained from treatment 4, since there is a synergy with $36 \mathrm{mM}$ of $\mathrm{H}_{2} \mathrm{O}_{2}$ and $0.1 \mathrm{mM}$ of $\mathrm{SA}$ with $36 \mathrm{mM}$ of $\mathrm{H}_{2} \mathrm{O}_{2}$. Treatment 5 with lower concentrations of $\mathrm{H}_{2} \mathrm{O}_{2}$ and $\mathrm{SA}$ showed the lowest intensity for aroma and flavor descriptors.

In Orangela, global aroma showed low intensities, in general, attributes related to aroma and flavors were negatively influenced by the treatments. Similar intensities were observed for the texture attributes, treatment 3 showed the highest intensities for cohesiveness (TBPCCoh) and external hardness (TBPCFirm). It seems that salicylic acid promoted the hardness of the pericarp in Orangela sweet peppers; on the other hand, first bite hardness (TBPCDur) intensity was decreased in all treatments. For both varieties, experimental treatments showed significant effects compared to the control treatment 1 .

The experimental treatments resulted in significant changes in aroma and texture for Fascinato, and in texture for Orangela, in both varieties especially for cohesiveness (TBPCCoh) and external hardness (TBPCFirm), global aroma was a distinctive attribute for Fascinato.

\section{Principal component analysis (PCA)}

In order to detect correlations between changes in intensity of sensory attributes and treatments the PCA was applied. Simultaneous plots of the score relationship (elicitor treatments) and loadings (sensory attributes) allowed visualizing the data. The eigenvalues as well as the cumulative variance are included in Table 4. Eigenvalues higher than 1.0 were selected to choose principal components.

As can be detected, most of the variation in the sensory data can be described by the first two components. The first principal component was capable to explain $81.02 \%$ of the variability. The second and third components were able to represent $9.24 \%$ and $6.08 \%$ of the variability, respectively. The eigenvalues for these three components are greater than 1.0.

Figure 2 shows the 2D biplots for both interpretations and the variables. It can be observed that treatment 2

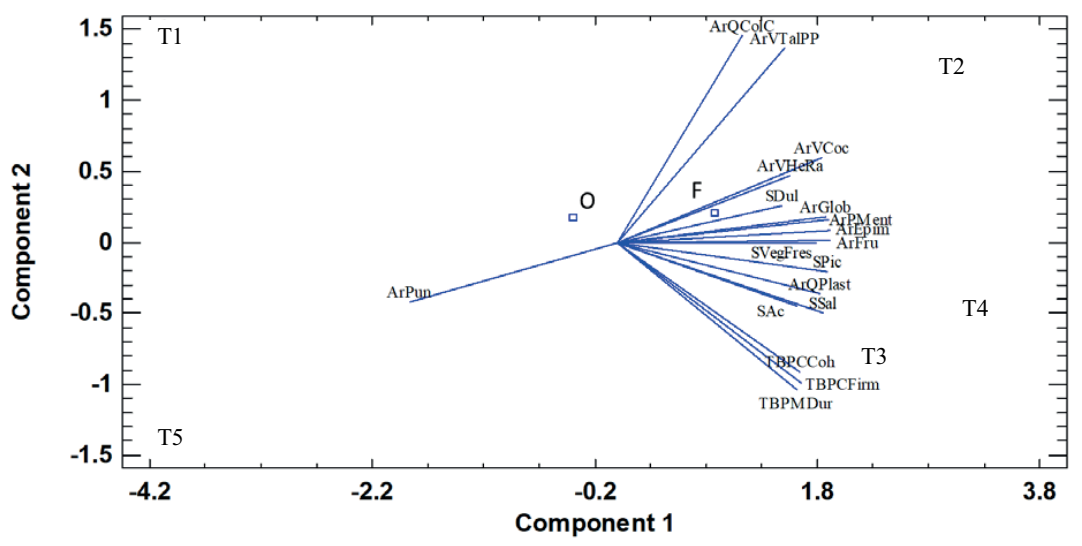

FIGURE 2. Biplots of the simultaneous evaluation of the relationship of scores (elicitor applications) and loadings (sensory attributes). Numbers in the figure indicate the number of the corresponding elicitor treatment. $\mathrm{F}=$ Fascinato, $\mathrm{O}=$ Orangela. 
TABLE 4. Variance explained and eigenvalues obtained by means of the principal component analysis.

\begin{tabular}{lcccc}
\hline $\begin{array}{l}\text { Component } \\
\text { number }\end{array}$ & Eigenvalue & $\begin{array}{c}\text { Percent } \\
\text { of variance }\end{array}$ & $\begin{array}{c}\text { Cumulative } \\
\text { percentage }\end{array}$ \\
\hline 1 & 14.58 & 81.02 & 81.02 \\
2 & 1.66 & 9.24 & 90.26 \\
3 & 1.09 & 6.08 & 96.34 \\
\hline
\end{tabular}

a Components with eigenvalues greater than or equal to 1.0 have been extracted to explain the variability in the original data.

and 4 were ranked highly on the positive part of the first component, in contrast treatments 1 and 5. On the low part of the graph, more related to the second component is treatment 3. There is a clear description about the influence of treatments on sweet pepper sensory traits. Treatments 2 and 4 were quite related to flavor and aroma characteristics. Treatment 2 was strongly related to traits such as chemicalSulphur (ArQColc) and vegetative-fresh (ArVTalPP), while treatment 4 was more related to flavor traits such as vegetative-fresh (ArTalPP), acid (SAc), salty (SSal), and aromas such as chemical-plastic (ARQPlast). Traits related to texture were characteristic of treatment 3. On the other hand, treatment 5 was related to pungent (ArPun) aroma. And as it can be expected, treatment 1 (control) showed no correlation with changes in sensory profile, it means that experimental treatments really affected the quality of sweet peppers.

The results for aroma profile in both varieties showed a high correlation of both with the first components; Fascinato variety was located in the positive part of the component, and on the opposite, the Orangela variety. It can be clearly seen that Fascinato was more susceptible to experimental treatments to modify its sensory profile. The main sensory traits characterizing this variety were related to flavor and aroma. Orangela, on the other hand, can only be related to pungent (ArPun) aroma. It seems that high concentrations of $\mathrm{H}_{2} \mathrm{O}_{2}$ were responsible for changes in the sensory profile of the evaluated samples since treatments 2 and 4 are related with changes in at least 14 sensory traits. A decrease in the concentration of this elicitor in treatment 5 caused no effect on sensory profile, and its absence (treatment 3 ) allowed only changes in texture profile. It was clear that no elicitor application had any effect on the sensory profile (treatment 1 ).

\section{DISCUSSION}

The effect of foliar applications of $\mathrm{H}_{2} \mathrm{O}_{2}$ and SA as elicitors on the sensory quality of sweet bell peppers was investigated. Elicitors are compounds which activate chemical defense in plants. Various biosynthetic pathways are activated in treated plants depending on the elicitor used [Thakur \& Sohal, 2013]. In consequence, the signal transduction paths promoted by elicitors lead to an elicitor-induced production of secondary metabolites important for quality of crops such as peppers [Zhao et al., 2005]. The results from the MANOVA analysis showed a significant effect of elicitors on aroma, flavor, and texture traits. Over the last decades, consumers have become more concern about sensory quality of products
[Eggink et al., 2012]. Many different types of aromas were promoted in the presence of elicitor treatments, such as global aroma, vegetative fresh (ArVTalPP), chemical Sulphur (ArQColc), and other related to pungency such as pungent-fresh (ArPMent) and pungent (ArPun), the latter descriptor is related with capsaicin content (responsible for the pungency) [Garruti et al., 2013] promoted by the presence of elicitors. It can be observed from the PCA analysis that treatment 5 was strongly related to this descriptor, and variety Orangela was also related to it. From Table 3 it was observed that most attributes where affected by variety, and when the treatments where selected as the factor, only 10 attributes where affected significantly. Treatments 2, 3 and 4 were responsible for such changes in most of the cases. The different concentrations of elicitors in these treatments could trigger the production of polyphenolic compounds in fruits [Ruiz-García \& Gómez-Plaza, 2013]. Polyphenolic compounds are secondary metabolites, they are important for fruit quality because they are responsible for the organoleptic and qualitative properties of fruits originated from the pre- and post-harvest treatments of plants and fruits with elicitors [Waterhouse, 2002]. Related studies reported similar results as Shafiee et al. [2010], who found that strawberries receiving SA in nutrient solution had less weight loss and decay and higher firmness. In the case of sweet bell pepper, applications of $0.1 \mathrm{mM}$ SA (treatments 3 and 4) produced changes in attributes related to firmness. In another related study, Elwan \& El-Hamahmy [2009] found that SA application at a low concentration $\left(1 \times 10^{6} \mathrm{M}\right)$ to sweet pepper positively increased the foliage fresh and dry weight, fruit number, average fruit weight, fruit yield, vitamin C, carotenoids content, cuticle thickness of fruit pericarp and translocation of sugars from leaves to fruits. It seems that SA applications promote changes in firmness-related traits, and in the content of secondary metabolites such as carotenoids and polyphenols.

Analyzing the PCA results, treatments 2 and 4 that in their cocktail of elicitors had $36 \mathrm{mM}$ of $\mathrm{H}_{2} \mathrm{O}_{2}$ were strongly correlated to component 1 which was described by many flavor and aroma traits. Many previous studies had discussed the role of $\mathrm{H}_{2} \mathrm{O}_{2}$ in extending the shelf life of peppers since it can act as a signaling compound [Lin et al., 2011; Bayoumi, 2008; Dat et al., 2000]. But the role of $\mathrm{H}_{2} \mathrm{O}_{2}$ in pre- and postharvest quality can be related to phenol and flavonoid content [Khandaker et al., 2012], increased sweetness and sugar composition [Ozaki et al., 2009], and fruit firmness [Nur Aida et al., 2010]. The results in this study indicate the possible influence of $\mathrm{H}_{2} \mathrm{O}_{2}$ on flavor and aroma compounds since treatment $2\left(36 \mathrm{mM} \mathrm{H}_{2} \mathrm{O}_{2}\right.$ ) was highly correlated to aromas such as vegetative cooked (ArVCoc), vegetative herbal (ArVHeRa), global aroma (ArGlob), pungent aroma (ArPun), spicy aroma (ArEPim), fruity aroma (ArFr), and flavors such as sweet (ArCCarM). On the other hand, when it was combined with SA in treatment 4, the correlation was higher in terms of traits such as flavor: vegetative fresh (ArVTalPP), spicy pungent (ArPalch), salty (SSal) and acid (SAc), and with aroma chemical plastic (ARQPlas). Pungent (ArPun) flavor is developed due to the presence of capsaicin in peppers. According to Thakur et al. [2017], SA dipping treatments for $5 \mathrm{~min}$ (1000 ppm) resulted in a low decrease in dry matter content and retained 
maximum capsaicin content, and dipping of pepper in $\mathrm{H}_{2} \mathrm{O}_{2}$ (15 mM) for 30 min was effective in reducing fruit spoilage.

\section{CONCLUSION}

In this study, it has been shown that elicitors modify the sensory quality traits of sweet pepper and that this effect depends on the variety of the sweet pepper. In overall, it can be concluded that $\mathrm{SA}$ and $\mathrm{H}_{2} \mathrm{O}_{2}$ promote changes in the aroma, flavor and texture traits mainly in treatments 2 and 4 which have the combination of $\mathrm{SA}$ and $\mathrm{H}_{2} \mathrm{O}_{2}$ and in treatment 2 and 3 that only have the effect of $\mathrm{H}_{2} \mathrm{O}_{2}$ and $\mathrm{SA}$ individually. On the other hand, statistical tools such as PCA, can be very useful for identifying modifications of sensory descriptors and for selecting variables to be used for evaluation. Results from this research show that pre-harvest treatment with the combination of SA and $\mathrm{H}_{2} \mathrm{O}_{2}$ can improve the sensory quality of peppers, and not only promote an increase in their shelf life, as shown in previous studies.

\section{ACKNOWLEDGEMENTS AND RESEARCH FUNDING}

M.I.A. Jimenez-Garcia Sandra Neli wants to thanks Consejo Nacional de Ciencia y Tecnologia (CONACyT) for her Ph.D. scholarship support contract number 424202 and wants to thank the collaboration of Koppert Research and Training Center (CEICKOR), in Queretaro for the technical support related crop cultural labor in greenhouse and biological control; and to Professor Maria Fernanda Gasca Aguilar for carrying out sensory analysis procedures. Also, we want to thank Fordecyt 193512, FOFIUAQ 2013, and CB-2012 NUM 179353 economic support for the realization of this research.

\section{CONFLICT OF INTERESTS}

The authors declare that there is no conflict of interests regarding the publication of this paper.

\section{REFERENCES}

1. Bayoumi Y.A., Improvement of postharvest keeping quality of white pepper fruits (Capsicum annuum L.) by hydrogen peroxide treatment under storage conditions. Acta Biol. Szeged., 2008, $52,7-15$.

2. Berrueta L.A., Alonso-Salces R.M., Héberger K., Supervised pattern recognition in food analysis. J. Chromat. A, 2007, 1158, 196-214.

3. Castro S.M., Saraiva J.A., Lopes-Da-Silva J.A., Delgadillo I., Loey A.V., Smout C., Hendrickx M., Effect of thermal blanching and of high pressure treatments on sweet green and red bell pepper fruits (Capsicum annuum L.). Food Chem., 2008, 107, 1436-1449.

4. Dat J., Vandenabeele S., Vranová E., Van Montagu M., Inzé D., Van Breusegem F., Dual action of the active oxygen species during plant stress responses. Cell. Mol. Life Sci., 2000, 57, 779-795.

5. Eggink P., Maliepaard C., Tikunov Y., Haanstra J., Bovy A., Visser R., A taste of sweet pepper: Volatile and non-volatile chemical composition of fresh sweet pepper (Capsicum annuum L.) in relation to sensory evaluation of taste. Food Chem., 2012, 132, 301-310.
6. Elwan M., El-Hamahmy M., Improved productivity and quality associated with salicylic acid application in greenhouse pepper. Sci. Hortic., 2009, 122, 521-526.

7. Garruti D.D.S., Pinto N.D.O.F., Alves V.C.C., Penha M.F.A.D., Tobaruela E.D.C., Araújo Í.M.D.S., Volatile profile and sensory quality of new varieties of capsicum Chinense pepper. Food Sci. Technol. (Campinas), 2013, 33, 102-108.

8. Guillén-Casla V., León-González M.E., Pérez-Arribas L.V., Polo-Díez L.M., Direct chiral determination of free amino acid Enantiomers by two-dimensional liquid chromatography: application to control transformations in E-beam irradiated foodstuffs. Anal. Bioanal. Chem., 2010, 397, 63-75.

9. Guzmán I., Bosland P.W., Sensory properties of Chile pepper heat - and its importance to food quality and cultural preference. Appetite, 2017, 117, 186-190.

10. Holopainen J., Heijari J., Nerg A., Vuorinen M., Kainulainen P., Potential for the use of exogenous chemical elicitors in disease and insect pest management of conifer seedling production. Open Forest Sci. J., 2009, 2, 17-24.

11. Ilić Z.S., Šunić L., Fallik E., Quality evaluation and antioxidant activity of mini sweet pepper cultivars during storage in modified atmosphere packaging (MAP). Romanian Biotechnol. Lett., 2017, 22, 12214-12223.

12. Jacxsens L., Devlieghere F., Debevere J., Temperature dependence of shelf-life as affected by microbial proliferation and sensory quality of equilibrium modified atmosphere packaged fresh produce. Postharv. Biol. Technol., 2002, 26, 59-73.

13. Khandaker M.M., Boyce A.N., Osman N., The influence of hydrogen peroxide on the growth, development and quality of wax apple (Syzygium Samarangense, [Blume] Merrill \& Lm Perry Var. Jambu Madu) fruits. Plant Physiol. Biochem., 2012, 53, 101-110.

14. Lin W.-C., Block G.S., Ehret D.L., The effect of H2O2 application during production on greenhouse pepper shelf life. Am. J. Plant Sci. Biotechnol., 2011, 5, 101-104.

15. Maalekuu K., Elkind Y., Tuvia-Alkalai S., Fallik E., Shalom Y., The influence of harvest season and cultivar type on several quality traits and quality stability of three commercial sweet bell peppers during the harvest period. Adv. Hortic. Sci. (Rivista dell'ortofloroftutticoltura italiana). 2004, 18, 1000-1005.

16. Meilgaard M.C., Carr B.T., Civille G.V., Sensory Evaluation Techniques, 2006. CRC Press.

17. Nur Aida M., Hairiyah M., Wan Mohd Reza W., Nur Ilida M., Effect of hydrogen peroxide on quality of fresh-cut pineapple stored at $5^{\circ} \mathrm{C}$. VII International Pineapple Symposium, 2010, 902, 493-498.

18. Ozaki K., Uchida A., Takabe T., Shinagawa F., Tanaka Y., Takabe T., Hayashi T., Hattori T., Rai A.K., Takabe T., Enrichment of sugar content in melon fruits by hydrogen peroxide treatment. J. Plant Physiol., 2009, 166, 569-578.

19. Rajalahti T., Kvalheim O.M., Multivariate data analysis in parmaceutics: A tutorial review. Int. J. Pharmaceut., 2011, 417, SI, 280-290.

20. Raybaudi-Massilia R., Suárez A.I., Arvelo F., Zambrano A., Sojo F., Calderón-Gabaldón M.I., Mosqueda-Melgar J., Cytotoxic, antioxidant and antimicrobial properties of red sweet pepper (Capsicum annuum L. Var. Llanerón) extracts: in vitro study. Int. J. Food Stud., 2017, 6, 222-231.

21. RodríGuez-Burruezo A.N., Kollmannsberger H., Gonzalez-Mas M.C., Nitz S., Fernando N., HS-SPME comparative analysis 
of genotypic diversity in the volatile fraction and aroma-contributing compounds of Capsicum fruits from the AnnuumChinense-Frutescens complex. J. Agric. Food Chem., 2010, 58, 4388-4400.

22. Ruiz-García Y., Gómez-Plaza E., Elicitors: A tool for improving fruit phenolic content. Agriculture, 2013, 3, 33-52.

23. Shafiee M., Taghavi T., Babalar M., Addition of salicylic acid to nutrient solution combined with postharvest treatments (hot water, salicylic acid, and calcium dipping) improved postharvest fruit quality of strawberry. Sci. Hortic., 2010, 124, 40-45.

24. Simões A.D., Tudela J.A., Allende A., Puschmann R., Gil M.I., Edible coatings containing chitosan and moderate modified atmospheres maintain quality and enhance phytochemicals of carrot sticks. Postharv. Biol. Technol., 2009, 51, 364-370.

25. Simonne A., Simonne E., Eitenmiller R., Mills H., Green N., Ascorbic acid and provitamin A contents in unusually colored bell peppers (Capsicum annuum L.). J. Food Comp. Anal., 1997, 10, 299-311.

26. Thakur K., Jyoti K., Kumar S., Gautum S., Improvement of postharvest keeping quality of bell pepper (Capsicum annum L.) fruits treated with different chemicals following cold storage. Int. J. Curr. Microbiol. Appl. Sci., 2017, 6, 7, 2462-2475.

27. Thakur M., Sohal B.S., Role of elicitors in inducing resistance in plants against pathogen infection: A review. ISRN Biochem., 2013, 2013, art. id. 762412 .
28. VanRuth S.M., Roozen J.P., Gas chromatography /sniffing port analysis and sensory evaluation of commercially dried bell peppers (Capsicum annuum) after rehydration. Food Chem., 1994, 51, 165-170.

29. Vargas M., Albors A., Chiralt A., González-Martínez C., Quality of cold-stored strawberries as affected by chitosan-oleic acid edible coatings. Postharv. Biol. Technol., 2006, 41, 164-171.

30. Waterhouse A.L., Wine phenolics. Alcohol and Wine in Health and Disease. Book Series. Ann. New York Acad. Sci., 2002, 957, 21-36.

31. Westad F., Hersleth M., Lea P., Martens H., Variable selection in PCA in sensory descriptive and consumer data. Food Qual. Pref., 2003, 14, 463-472.

32. Zhao J., Davis L.C., Verpoorte R., Elicitor signal transduction leading to production of plant secondary metabolites. Biotechnol. Adv., 2005, 23, 283-333.

33. Zimmermann M., Schieberle P., Important odorants of dweet bell pepper powder (Capsicum annuum cv. Annuum): Differences between samples of Hungarian and Morrocan origin. Eur. Food Res. Technol., 2000, 211, 175-180.

Submitted: 15 December 2016. Revised: 29 July, 12 September, 27 September and 8 December 2017. Accepted: 7 March 2018. Published on-line: 9 May 2018. 